[Type text]

JOSAR, Vol. 1 No. 1 March 2019; p-ISSN: 2502-8251; e-ISSN: 2503-1155

Copyrights@Balitar Islamic University, Blitar-Indonesia https://ejournal.unisbablitar.ac.id/index.php/josar

\title{
Developing Information System of Management Archieving Corresponding Mail BASED ON WEBSITE
}

\author{
Dimas Fanny Hebrasianto Permadi ${ }^{1}$ \\ 1)FakultasTeknologilnformasi, Universitas Islam Balitar \\ e-mail: dime.ask@gmail.com ${ }^{1)}$
}

\begin{abstract}
:
Administration is part of the institution authorized to handle documents and archiving. The archiving mail is required for management mail data. The problem is the mail archiving still using hardfile like the result of print out from Office Application such as Microsoft Word. The archiving mail is like writing the data on incoming and outgoing mail in the report's book. Because of that, The management of letters using the print out is oftenerrors in storing mail data. Applications corresponding aims to change the way storage is hardfile letter into tangible softfile mail archives, making it easier to perform archiving these letters as a database.This application is built using waterfall method which the plot carried out gradually. The result of this application is the officer used this application more helpful for correspondences and improve the satisfaction level of its work is increasing by $12.19 \%$ from83.13\% for manually to the digitally at $83.13 \%$
\end{abstract}

Keywords : Mail Archiving,Management Corresponding, Information System

\section{Introduction}

A Ninstance must have important documents such as incoming mail and outgoing mail. Correspondence activities must get serious attention. Because the contents of the letter, for instance, become a means of achieving the objectives of the instance concerned. Therefore, letter management is needed [1]. The results from printed letters still use files manually in the form of a report book. However, the archiving that mailsare still manual. File archiving by manual shows weaknesses. Because of that, we need a better file archiving by developing an information system based on a computer.

Information system based on the computer is needed in every organization. The information system, in this case, aims to facilitate the archiving of correspondences. This information system is minimizing human error that occurs in registration and archiving correspondence and facilitates reporting and accountability for those in need[2] [3].

\section{Study Literature}

Letters are defined as one of the written communication media to convey information[2]. Based on its contents, the letter is a type of essay, because the sender of the letter expresses the intent and purpose, explains what he thinks and feels through the letter. 
JOSAR, Vol. 1 No. 1 March 2019; p-ISSN: 2502-8251; e-ISSN: 2503-1155

Copyrights@Balitar Islamic University, Blitar-Indonesia https://ejournal.unisbablitar.ac.id/index.php/josar

Based on the form of losses, a letter is written a conversation, from a person to person, from one person to the institution, from the institution to a person, or of the institution to[4].Archiving mail storing of various documents from any instance activity [1]. Archiving system is a record of recording activities or sources of information with various forms made by institutions, organizations, and individuals in the context of carrying out activities[5].

Digital archiving is storing document into the computer. This is going to paperless. Archiving document in the computer is useful for finding the old document. This is easier than it must be looking for where is it that document. Also, paperless can save space work[6]. In the future, document archiving will continue to increase in every instance. Therefore, archiving is needed to be an organized document for increasing the productivity of the instances[7].

Research Method

This research is descriptive research that explains the process of developing Information System archiving including the development of applications for this system. The purpose of the descriptive method means to describe the conditions that occur in the present or ongoing[8].

\section{Problem analyzing}

In this part, we are analyzing the requirement system is needed. This problem is how to archiving incoming and outgoing letter for an instance.

\section{Collecting data}

Data was collected is used in this research. This data is including explained how to process corresponding incoming and outgoing letters.

\section{System development}

This part is designing a system in the form of database design that is used in the form of tables, design system behavior, system activities and design class requirements of the system. Design of user interface and process. 
JOSAR, Vol. 1 No. 1 March 2019; p-ISSN: 2502-8251; e-ISSN: 2503-1155

Copyrights@Balitar Islamic University, Blitar-Indonesia https://ejournal.unisbablitar.ac.id/index.php/josar

\section{Evaluation}

Evaluation is important in this part. Evaluationsare conducted on the prototype that has been developed if itis needed to be changed and fixed according to requirement.

\section{Result}

In this part is the final goal of this research which is this application can be implemented in the instance.

System Development

\section{Flowchart system}

A flowchart is a graphical image that shows the flow of data from the source in the object then passes through a process that transforms the other destination, which is in another object

\section{Flowchart user login}

This flowchart is describing how to process user login. This flowchart can be shown in fig 1 .

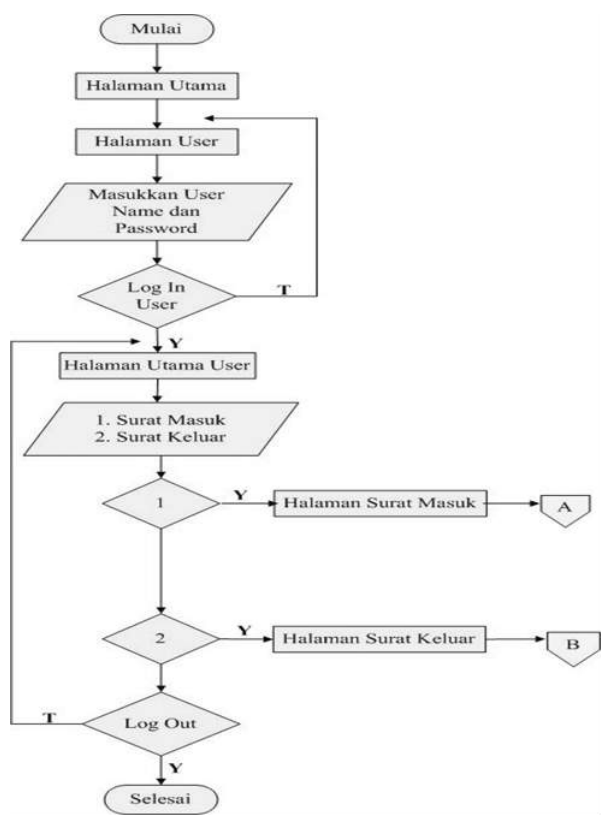

Figure. 1. Flowchart user login 
[Type text]

JOSAR, Vol. 1 No. 1 March 2019; p-ISSN: 2502-8251; e-ISSN: 2503-1155

Copyrights@Balitar Islamic University, Blitar-Indonesia https://ejournal.unisbablitar.ac.id/index.php/josar

\section{Flowchart admin login}

This flowchart is describing how to process user login. This flowchart can be shown in fig 2 .

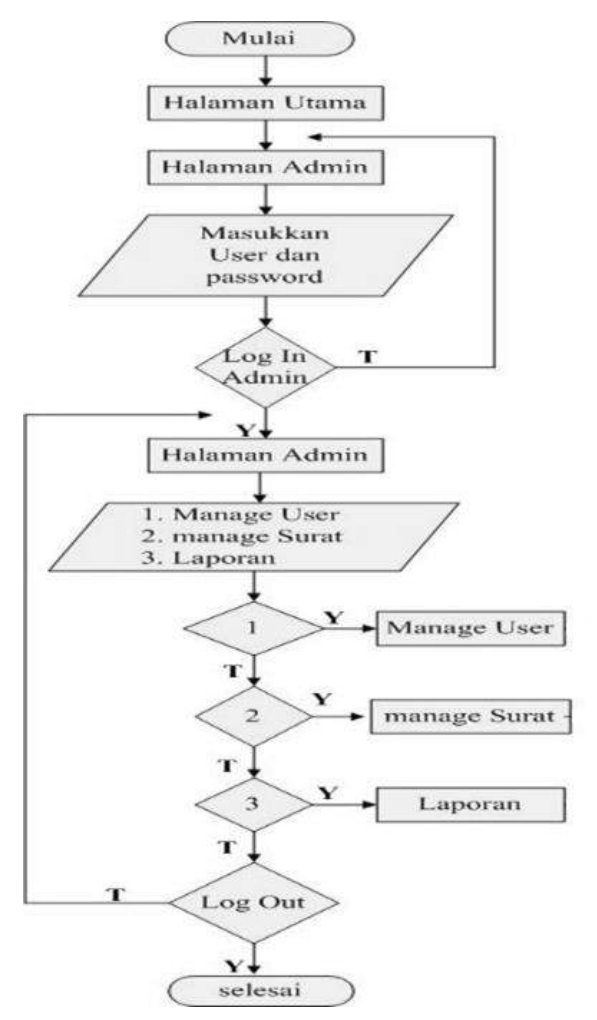

Figure. 2. Flowchart admin login 
[Type text]

JOSAR, Vol. 1 No. 1 March 2019; p-ISSN: 2502-8251; e-ISSN: 2503-1155

Copyrights@Balitar Islamic University, Blitar-Indonesia

https://ejournal.unisbablitar.ac.id/index.php/josar

\section{Flowchart incoming mail}

This flowchart is describing how to process incoming mail. This flowchart can be shown in fig 3 .
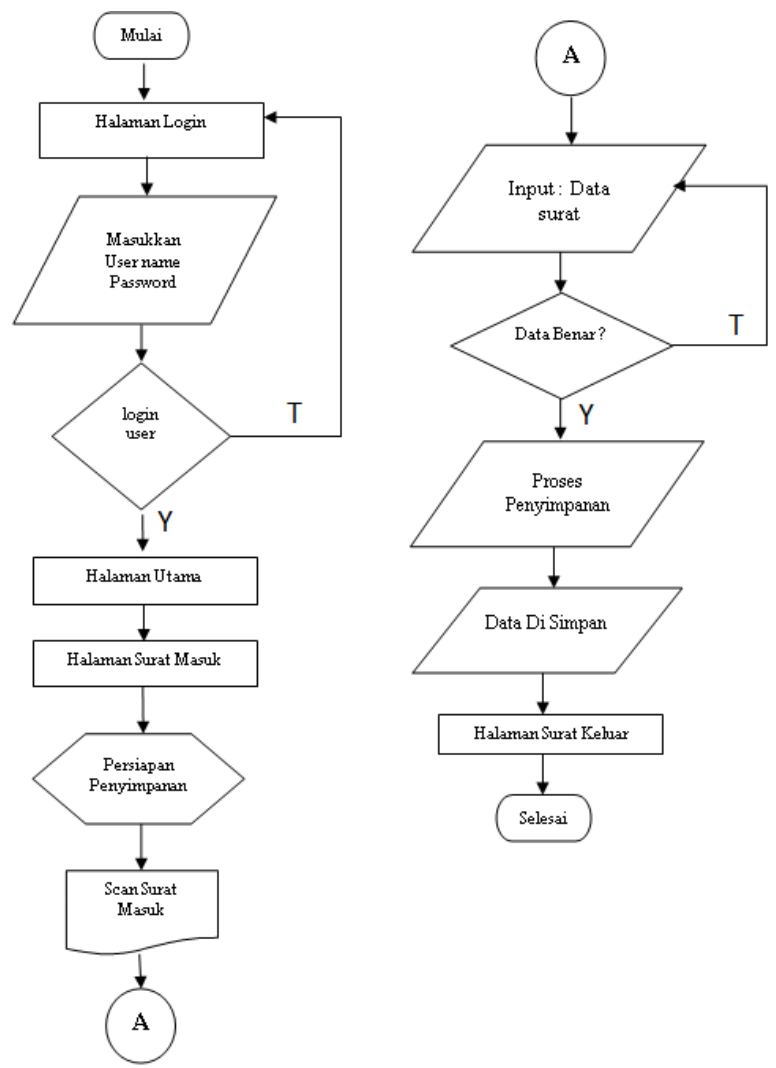

Figure. 3. Flowchart incoming mail 
[Type text]

JOSAR, Vol. 1 No. 1 March 2019; p-ISSN: 2502-8251; e-ISSN: 2503-1155

Copyrights@Balitar Islamic University, Blitar-Indonesia

https://ejournal.unisbablitar.ac.id/index.php/josar

\section{Flowchart outgoing mail}

This flowchart is describing how to process outgoing mail. This flowchart can be shown in fig 4 .
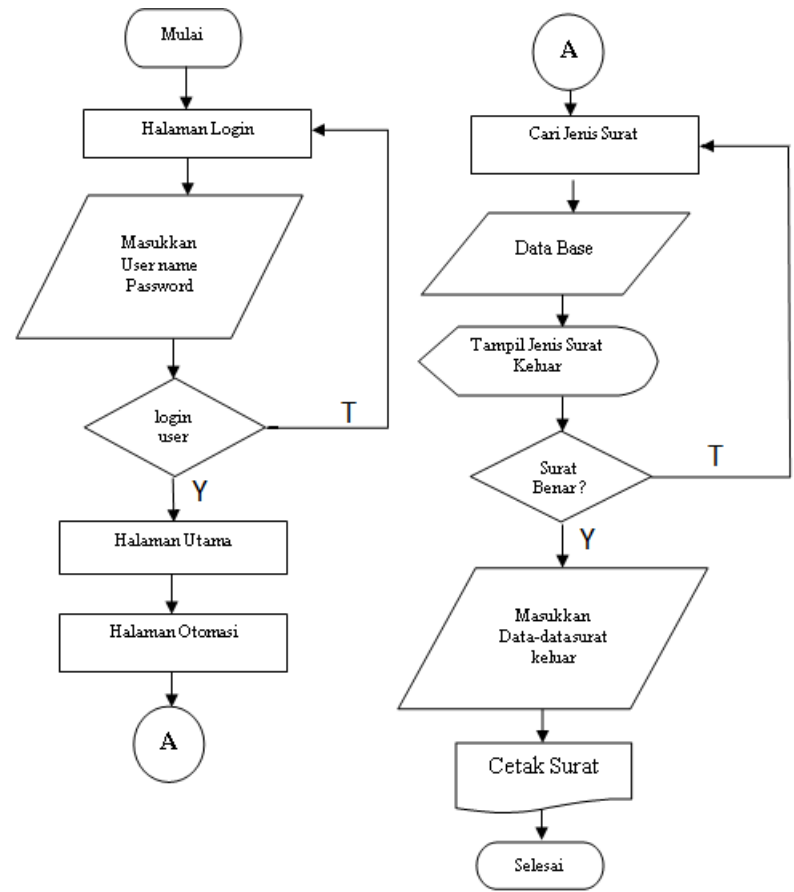

Figure. 4. Flowchart outgoing mail

\section{Entity Relationship Diagram (ERD)}

ERD is a picture or diagram showing the information created, stored, and used in the system. This information system ERD can be shown in Fig 5 


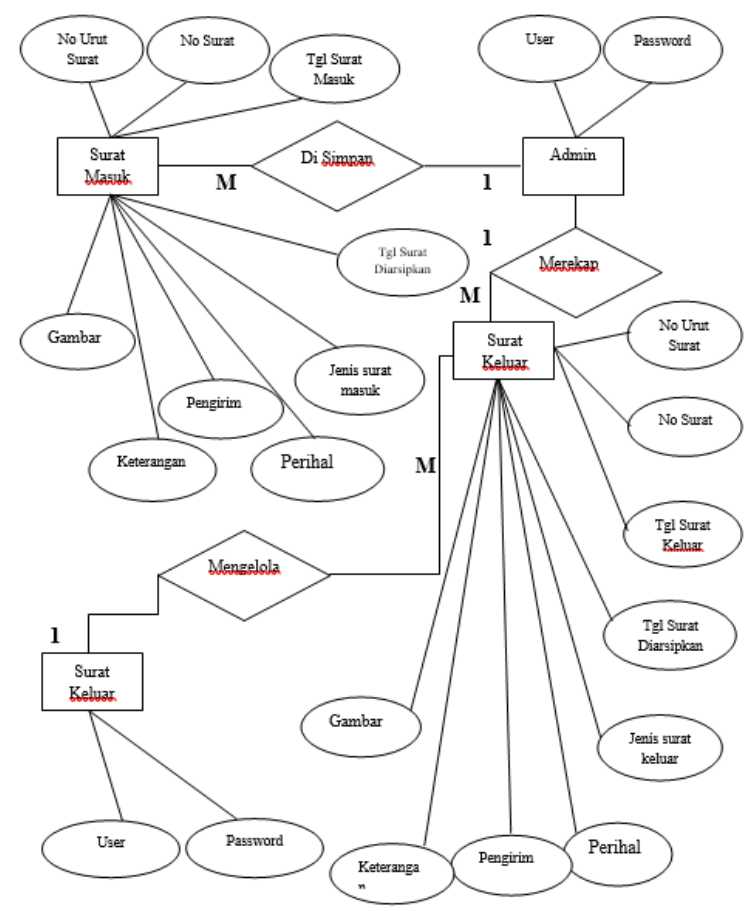

Figure. 5. ERD Archiving mail Information System

\section{Data Flow Diagram (DFD)}

This DFD image starts from the user receiving or making an outgoing letter and the letter will be processed by a system that will be used by the admin. Admin can edit or update, delete, and select, after that the user will get the report letter. This DFD can be shown in fig 6 . 
JOSAR, Vol. 1 No. 1 March 2019; p-ISSN: 2502-8251; e-ISSN: 2503-1155

Copyrights@Balitar Islamic University, Blitar-Indonesia https://ejournal.unisbablitar.ac.id/index.php/josar

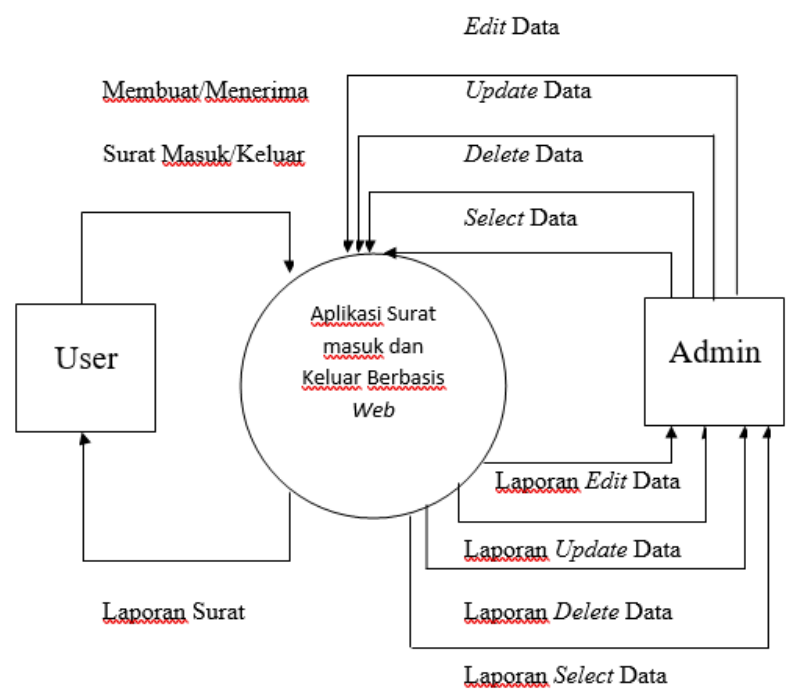

Figure. 6. DFD level 0 Archiving mail Information System

\section{Results and Discussions}

\section{Results}

The correspondence management system includes the ability to access filing, archiving, reporting, and tracking incoming and outgoing mail more effectively. Including in terms of time management, security, and structured and facilitate the administrationof correspondence at the Education Office of the City of Blitar.

\section{Menu structure}

The structure menu system in fig. 8 is divided by user login as user and admin. The user only managesto archive mail, editing incoming mail. Such as where is the incoming mail come from and who sent incoming mail. The user also can create or list outgoing mail. Admin can manage user, such as add, delete, or edit user data. Admin also can manage incoming and outgoing mail from the user. Admin can create report book from the user. Report book can be published every month or year.

\section{User Login page}

The login page can be shown in fig 7 . This page contains a username and password for the user. 
[Type text]

JOSAR, Vol. 1 No. 1 March 2019; p-ISSN: 2502-8251; e-ISSN: 2503-1155

Copyrights@Balitar Islamic University, Blitar-Indonesia https://ejournal.unisbablitar.ac.id/index.php/josar

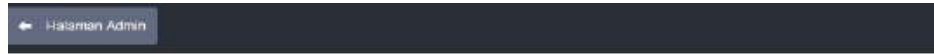

DIKDA KOTA BUTAR DINAS PENDIDIKAN DAERAH KOTA BLITAR

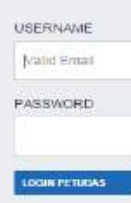

(3) Lodin untik miencatses halaman Poltugads

Figure. 7. User Login Page

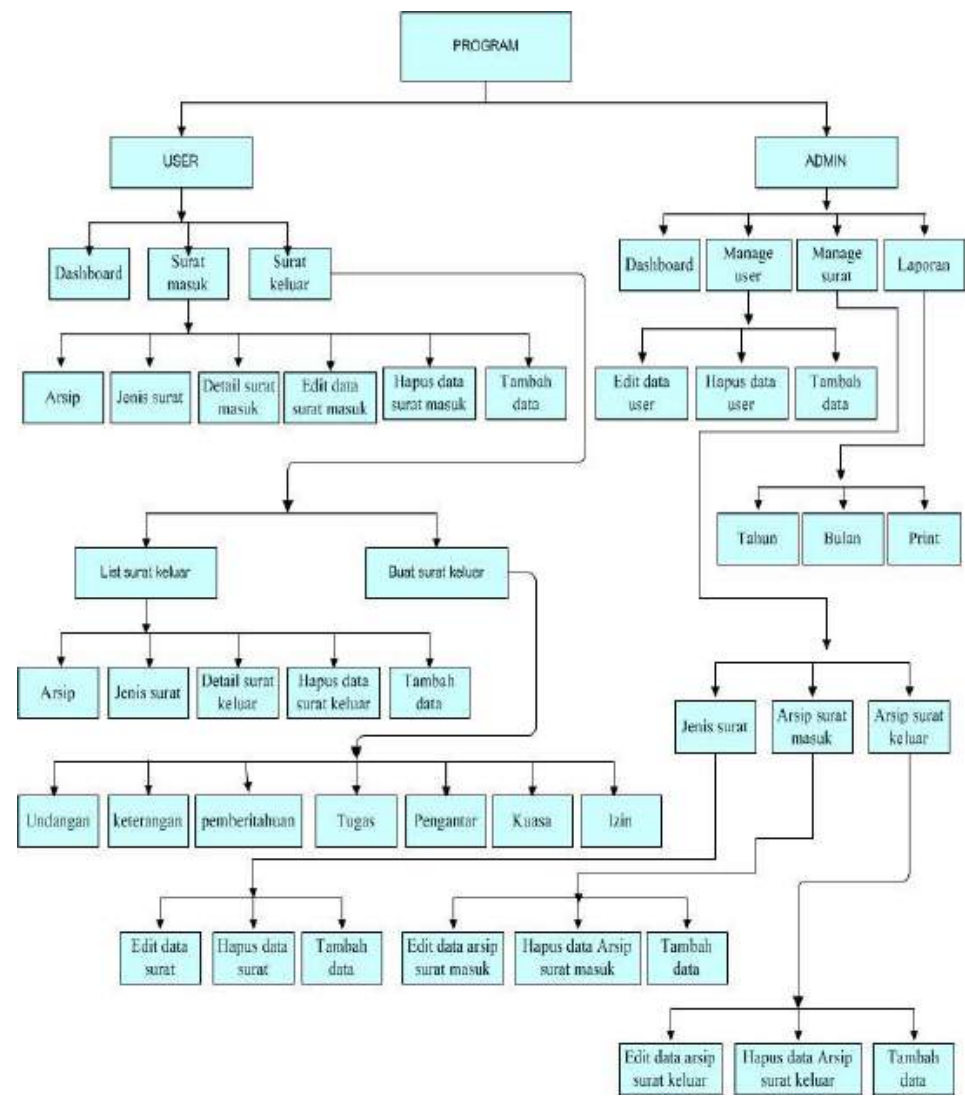

Figure. 8. Menu structurearchiving mail Information System 
JOSAR, Vol. 1 No. 1 March 2019; p-ISSN: 2502-8251; e-ISSN: 2503-1155

Copyrights@Balitar Islamic University, Blitar-Indonesia https://ejournal.unisbablitar.ac.id/index.php/josar

\section{Incoming mail dashboard for user}

This page in fig. 9 contains a detail of the incoming mail is containinga number of letters, subject, reserved, and date.

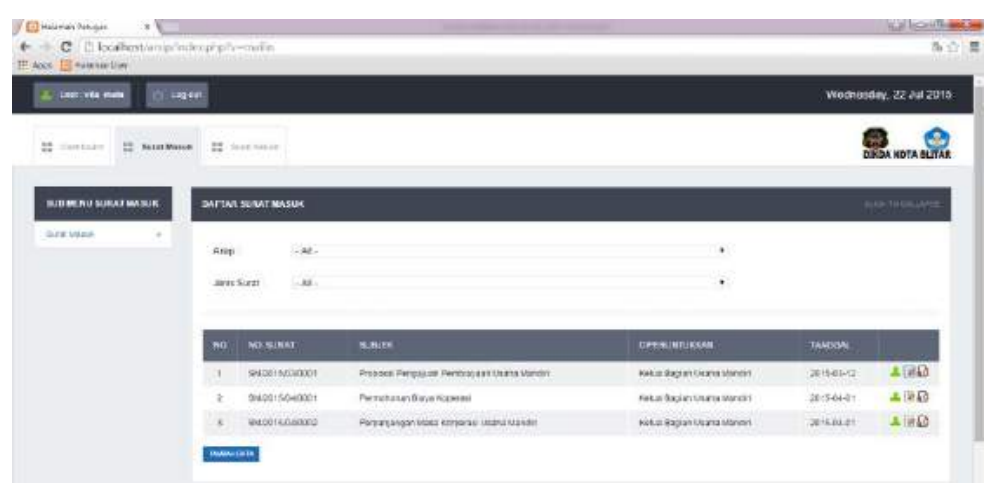

Figure. 9. Incoming mail dashboard for user

\section{Detail incoming mail page}

Fig 10 explain about detail kind of incoming mail. This is containing incoming mail date, archiving mail date, type of letters such as invitation or meeting letter, number of letters, destination letter, sender, and subject.

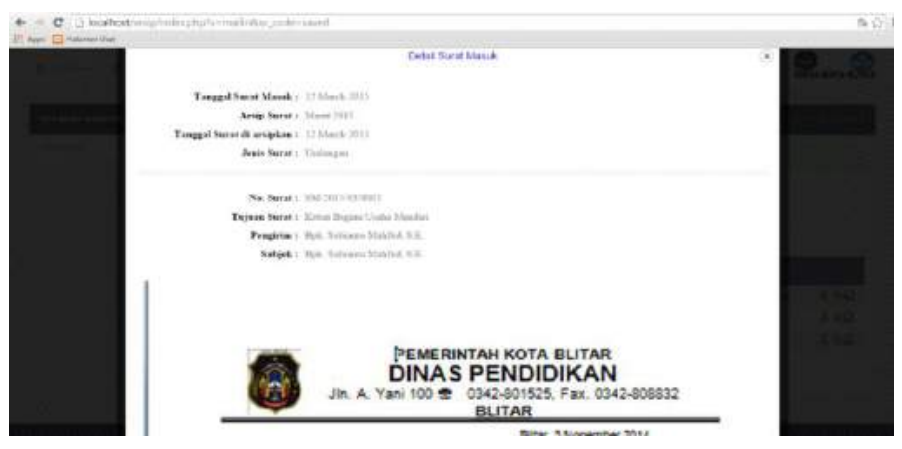

Figure. 10. Detail Incoming mail

\section{Add archiving incoming mail}

Fig 11 explain that contains archive date, destination letter, sender, subject, and note 
[Type text]

JOSAR, Vol. 1 No. 1 March 2019; p-ISSN: 2502-8251; e-ISSN: 2503-1155

Copyrights@Balitar Islamic University, Blitar-Indonesia https://ejournal.unisbablitar.ac.id/index.php/josar

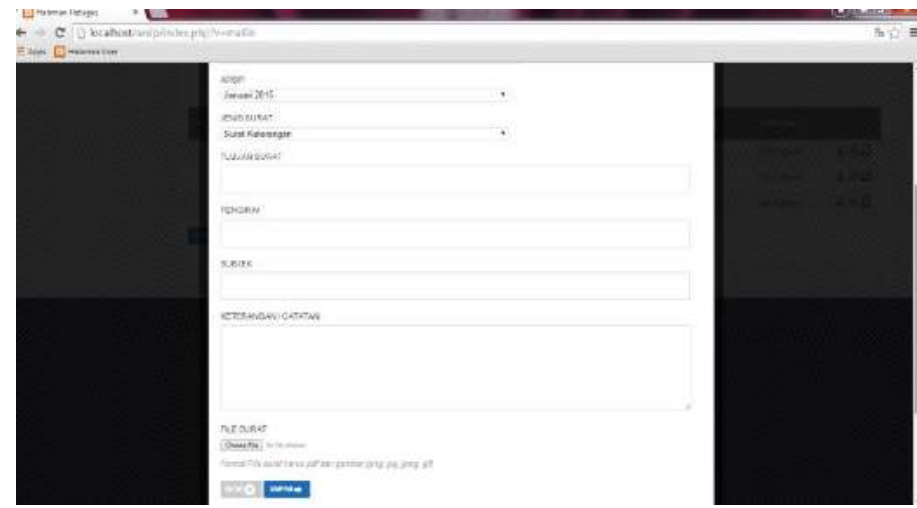

Figure. 11. Archiving Incoming mail

\section{List Outgoing mail dashboard for user}

Fig 12 explain that contains a list of all outgoing mail

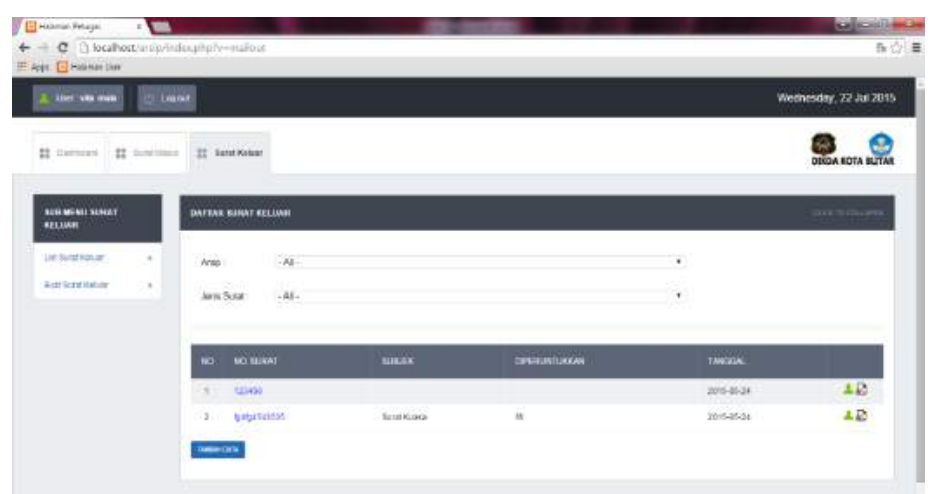

Figure. 12. List outgoing mail

\section{List Creating outgoing mail}

Fig 13 explain that kind of outgoing mail. This page contains invitation mail, testimonial mail, notification mail, cover mail, procuration mail, and permission mail 
[Type text]

JOSAR, Vol. 1 No. 1 March 2019; p-ISSN: 2502-8251; e-ISSN: 2503-1155

Copyrights@Balitar Islamic University, Blitar-Indonesia

https://ejournal.unisbablitar.ac.id/index.php/josar

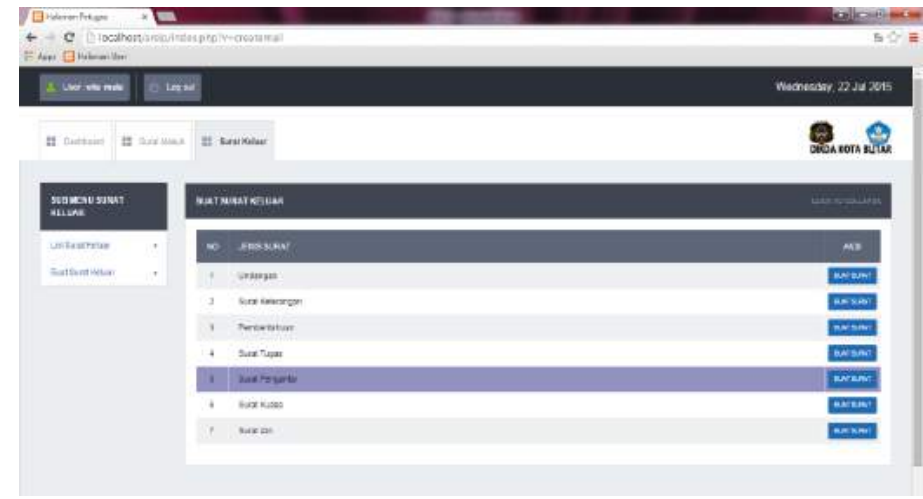

Figure. 13.List creating outgoing mail

\section{Creating outgoing mail}

Fig 14 explains that after choose kind of outgoing mail. For example is invitation mail, that contains archive date, mail number, mail date, trait mail, attachment, subject matter, to the honorable, content of the mail.

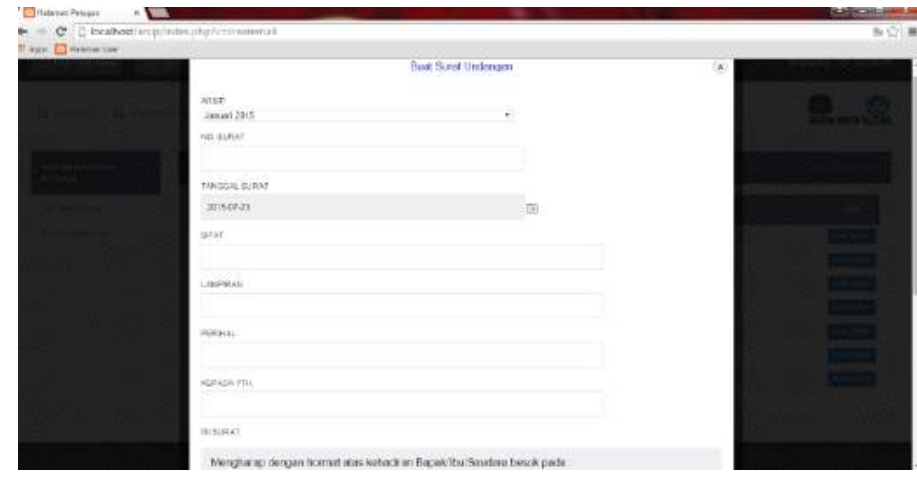

Figure. 14.Detail of invitation mail

\section{Managing incoming mail for admin}

This page admin can manage incoming mail such as delete, edit or add mail. It is can be shown in fig 15 
JOSAR, Vol. 1 No. 1 March 2019; p-ISSN: 2502-8251; e-ISSN: 2503-1155

Copyrights@Balitar Islamic University, Blitar-Indonesia https://ejournal.unisbablitar.ac.id/index.php/josar

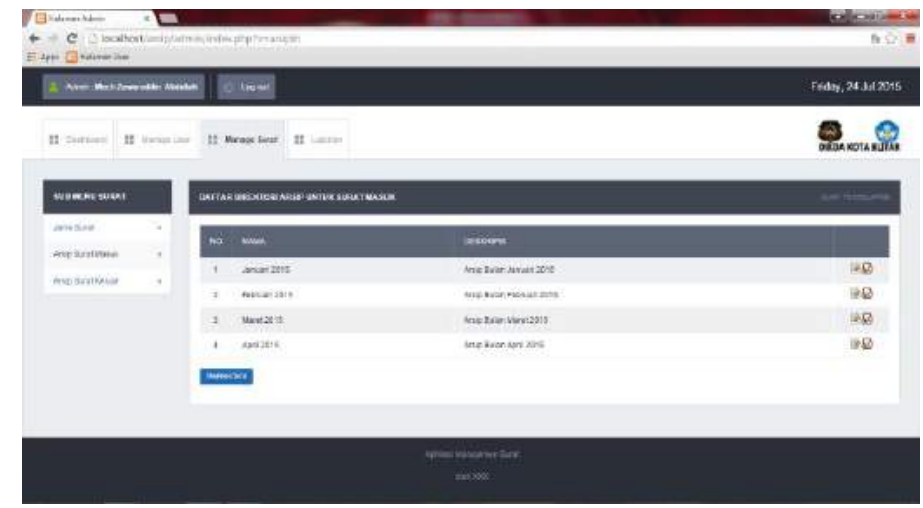

Figure. 15.List of incoming mail for Admin

\section{Managing outgoing mail for admin}

This page admin can manage outgoing mail such as delete, edit or add mail. It is can be shown in fig 16

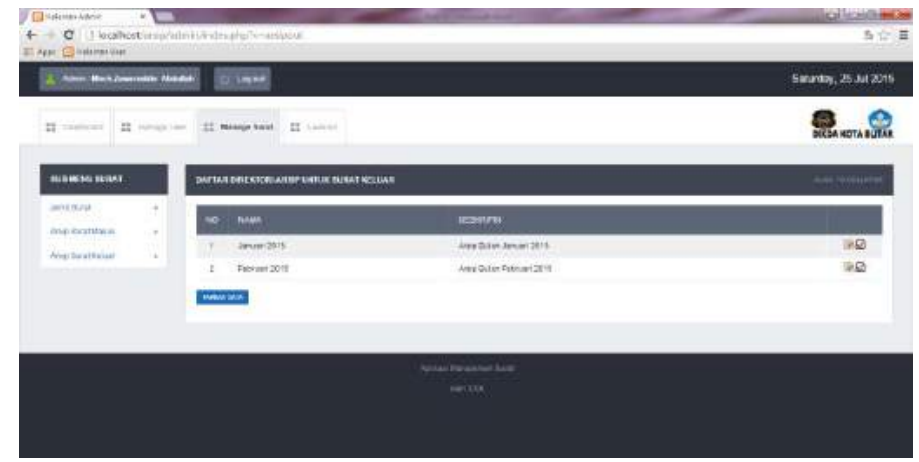

Figure. 16.List of outgoing mail for Admin

\section{Discussion}

This research was tested by users who worked at those places by 8 peoples. The age of users between 25-45 years old. The data tested is how the differences in satisfaction level between document archiving in a manual and digital system.Category of tested is archiving mail, creating mail, searching mail, and reporting mail. For the testing of the category is using by the questionaries how many percentages for every respondent between manual and digital system. The result data can be shown in Table 1 as manual archiving mail and Table 2 as digital archiving mail. 
[Type text]

JOSAR, Vol. 1 No. 1 March 2019; p-ISSN: 2502-8251; e-ISSN: 2503-1155

Copyrights@Balitar Islamic University, Blitar-Indonesia https://ejournal.unisbablitar.ac.id/index.php/josar

Table I. Satisfaction Percentage of Manual Archiving Mail

\begin{tabular}{|c|c|c|c|c|c|}
\hline $\begin{array}{c}\text { RESPONDEN } \\
\mathrm{T}\end{array}$ & $\begin{array}{c}\text { ARCHIVIN } \\
\text { G MAIL } \\
(\%)\end{array}$ & $\begin{array}{c}\text { CREATIN } \\
\text { G MAIL } \\
(\%)\end{array}$ & $\begin{array}{c}\text { SEARCHIN } \\
\text { G MAIL (\%) }\end{array}$ & $\begin{array}{c}\text { REPORTIN } \\
\text { G MAIL (\%) }\end{array}$ & $\begin{array}{c}\text { AVERAGE } \\
\mathrm{S}(\%)\end{array}$ \\
\hline 1 & 70 & 75 & 70 & 75 & 72.50 \\
\hline 2 & 75 & 70 & 70 & 70 & 71.25 \\
\hline 3 & 70 & 65 & 70 & 70 & 68.75 \\
\hline 4 & 65 & 70 & 70 & 75 & 70 \\
\hline 5 & 60 & 60 & 70 & 70 & 65 \\
\hline 6 & 80 & 70 & 70 & 75 & 73.75 \\
\hline 7 & 75 & 75 & 75 & 75 & 75 \\
\hline 8 & 70 & 75 & 70 & 70 & 71.25 \\
\hline AVERAGE & 70.63 & 70 & 70.63 & 72.50 & 70.94 \\
\hline
\end{tabular}

Table II. Satisfaction Percentage of Digital Archiving Mail

\begin{tabular}{|c|c|c|c|c|c|}
\hline RESPONDENT & $\begin{array}{c}\text { ARCHIVING } \\
\text { MAIL (\%) }\end{array}$ & $\begin{array}{c}\text { CREATING } \\
\text { MAIL }(\%)\end{array}$ & $\begin{array}{c}\text { SEARCHING } \\
\text { MAIL (\%) }\end{array}$ & $\begin{array}{c}\text { REPORTING MAIL } \\
(\%)\end{array}$ & $\begin{array}{c}\text { AVERAGES } \\
(\%)\end{array}$ \\
\hline 1 & 80 & 80 & 80 & 80 & 80 \\
\hline 2 & 85 & 80 & 90 & 80 & 83.75 \\
\hline 3 & 70 & 85 & 70 & 80 & 76.25 \\
\hline 4 & 85 & 95 & 85 & 85 & 87.50 \\
\hline 5 & 80 & 90 & 90 & 85 & 86.25 \\
\hline 6 & 80 & 85 & 85 & 80 & 82.50 \\
\hline 7 & 85 & 95 & 80 & 90 & 87.50 \\
\hline 8 & 80 & 85 & 80 & 80 & 81.25 \\
\hline
\end{tabular}


JOSAR, Vol. 1 No. 1 March 2019; p-ISSN: 2502-8251; e-ISSN: 2503-1155

Copyrights@Balitar Islamic University, Blitar-Indonesia https://ejournal.unisbablitar.ac.id/index.php/josar

\begin{tabular}{|c|c|c|c|c|c|}
\hline RESPONDENT & $\begin{array}{c}\text { ARCHIVING } \\
\text { MAIL (\%) }\end{array}$ & $\begin{array}{c}\text { CREATING } \\
\text { MAIL }(\%)\end{array}$ & $\begin{array}{c}\text { SEARCHING } \\
\text { MAIL }(\%)\end{array}$ & $\begin{array}{c}\text { REPORTING MAIL } \\
(\%)\end{array}$ & $\begin{array}{c}\text { AVERAGES } \\
(\%)\end{array}$ \\
\hline AVERAGE & 80.63 & 86.88 & 82.50 & 82.50 & 83.13 \\
\hline
\end{tabular}

Table III. Averages Satisfaction Percentage of Archiving Mail

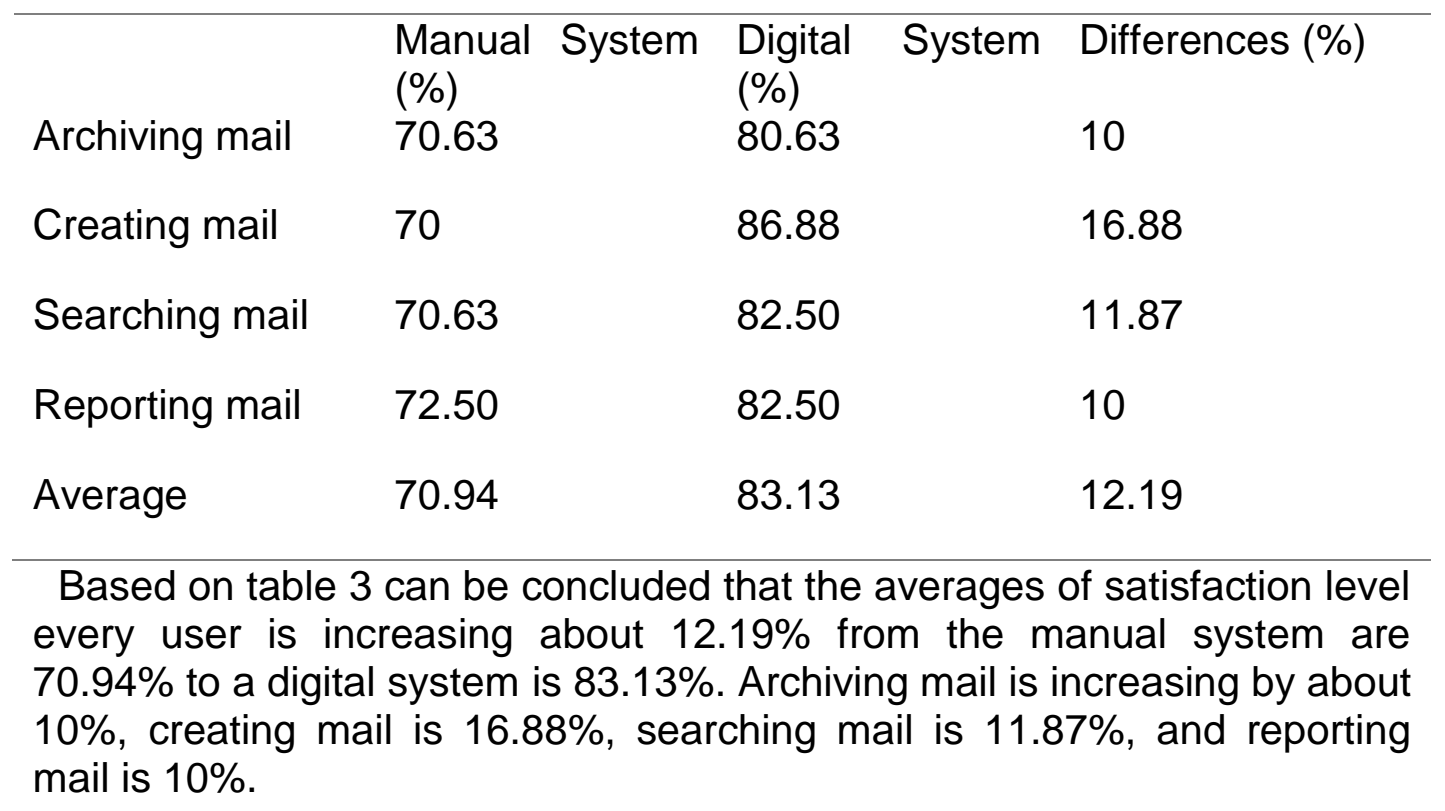

\section{VI.Conclusion}

The conclusions of this research are the satisfaction level of the digitalizing system from manual system about Archiving mail is increasing by about $12.19 \%$. Of course, the increasing satisfaction level from user it can increase productivity for documenting and archiving data. Also, it can save many spaces in the working space.

Suggestion

Although the satisfaction level is increasing, this research still has a weakness. This weakness can be mentioned that there is still a lack of data security, a search feature that is easier for example by providing input 
JOSAR, Vol. 1 No. 1 March 2019; p-ISSN: 2502-8251; e-ISSN: 2503-1155

Copyrights@Balitar Islamic University, Blitar-Indonesia https://ejournal.unisbablitar.ac.id/index.php/josar

a keyword to display letters that have been selected based on keywords, adding a document print feature automatically.

\section{REFERENCES}

[1] A. Vironica and S. , "Rancang Bangun Aplikasi Pengelolaan Surat Masuk Dan Surat Keluar Pada Sekolah Menengah Pertama Negeri 2 Nawangan," Journal Speed - Sentra Penelitian Engineering dan Edukasi , 2013.

[2] I. Suriatno and D. H. U.N., "SISTEM MANAJEMEN PENGARSIPAN SURAT MENYURAT PADA SETDA KABUPATEN SARMI-PAPUA," in Prosiding SINTAK 2017, 2017.

[3] R. A. Pascapraharastyan, A. Suprianto and P. Sudarminingtyas, "Rancang bangun sistem informasi manajemen arsip rumah sakit bedah Surabaya berbasis web," STMIK STIKOM , 2014.

[4] O. D. Prasetya and S. , "SISTEM INFORMASI PENGARSIPAN DATA SURAT MASUK DAN SURAT KELUR PADA POLRESTABES SEMARANG," UDiNus Repository, 2014.

[5] S. Lolong, "Sistem Pengarsipan Surat Keputusan Di Universitas Klabat," Cogito Smart Journal, 2018.

[6] S. Kimmel, "Go Paperless With a Digital Filing System," Amazon, 33 2017. [Online]. Available: https://www.techlicious.com/tip/how-to-gopaperless-with-digital-filing-system/. [Accessed 199 2018].

[7] A. Simangunsong, "Sistem Informasi Pengarsipan Dokumen Berbasis Web," Jurnal Mantik Penusa, vol. 2, 2018.

[8] S. Metode Penelitian Kuantitatif, Kualitatif dan R\&D, Bandung: Alfabeta, 2010. 
